\title{
Work-Related Flow Inventory: Evidence of Validity of the Brazilian Version
}

\author{
Clarissa Pinto Pizarro de Freitas², Bruno Figueiredo Damásio ${ }^{3}$, Emily Jean Haddad ${ }^{4}$, Silvia Helena Koller ${ }^{4}$ \\ ${ }^{2}$ Universidade Salgado de Oliveira, Niterói-RJ, Brazil \\ ${ }^{3}$ Universidade Federal do Rio de Janeiro, Rio de Janeiro-RJ, Brazil \\ ${ }^{4}$ Universidade Federal do Rio Grande do Sul, Porto Alegre-RS, Brazil
}

\begin{abstract}
Flow in work is constituted by the positive experiences and mental state experienced during the day-to-day occupational activities. This study aims to adapt and assess the psychometric properties of the Brazilian Version of the Work Related Flow Inventory (WOLF). Participants were a nationwide sample of 640 professional (74\% women), aged 19 to 73 years $(M=35.9$, $S D=10.5$ ). Confirmatory factor analyses (CFA) supported the oblique three-factor structure (absorption, work enjoyment and intrinsic work motivation) as being the most reliable to the data. Multigroup CFA achieved full measurement invariance for the gender and employment status (autonomous and non-autonomous). Flow dimensions were positively related to occupational selfefficacy and job satisfaction. WOLF presented adequate psychometric properties, suggesting its usefulness in evaluating flow at work in the Brazilian context.
\end{abstract}

Keywords: well-being, scaling, adaptation, factor analysis

\section{Inventário de Flow no Trabalho: Evidências de Validade da Versão Brasileira}

Resumo: Flow no trabalho constitui-se pelas experiências positivas e estado mental vivenciados durante as atividades ocupacionais do dia a dia. Este estudo tem como objetivo adaptar e avaliar as propriedades psicométricas da versão Brasileira do Inventário de Flow no Trabalho (WOLF). Os participantes desta pesquisa foram uma amostra nacional de 640 profissionais ( $74 \%$ mulheres), idades entre 19 a 73 anos $(M=35,9, \mathrm{DP}=10,5)$. A análise fatorial confirmatória (AFC) evidenciou a estrutura de três fatores oblíquos (absorção, envolvimento e motivação intrínseca) como a mais adequada aos dados. A AFC Multigrupo demonstrou a invariância da escala para sexo e situação de trabalho (autônomo e não-autônomo). As dimensões de flow estiveram positivamente relacionadas à autoeficácia ocupacional e satisfação no trabalho. WOLF apresentou propriedades psicométricas satisfatórias, sugerindo a sua utilidade para avaliar flow no contexto brasileiro.

Palavras-chave: bem-estar, escalas, adaptação, análise fatorial

\section{Inventario de Flow en Trabajo: Evidencia de Validez de la Versión Brasileña}

Resumen: El flow en trabajo comprende una experiencia positiva y estado mental que pueden ocurrir durante las actividades laborales. Este estudio pretende adaptar y evaluar las propiedades psicométricas de la versión brasilera del Inventario de Flow en trabajo (WOLF). Los participantes fueron una muestra nacional de 640 profesionales (74\% mujeres) con edades entre 19 a 73 años $(\mathrm{M}=35,9, \mathrm{DE}=10,5)$. El análisis factorial confirmatorio (AFC) respaldó que la estructura oblicua de tres factores (absorción, implicación y motivación intrínseca) es la más confiable. El AFC multigrupo alcanzó invariancia de medida completa para sexo y status de empleo (autónomo y no autónomo). Las dimensiones del flow se relacionaron positivamente con autoeficacia ocupacional y satisfacción laboral. El WOLF presentó propiedades psicométricas adecuadas, lo que sugiere su utilidad en evaluar flow en el contexto brasilero.

Palabras clave: bienestar, escalas, adaptación, análisis factorial

Flow is constituted by a positive experience and mental state also referred to as "the zone". It is characterized by an individual's ability to keep their attention focused on activities without effort and at the same time, enjoy involvement in the process of the activity (Csikszentmihalyi,

Correspondence address: Clarissa Pinto Pizarro de Freitas. Universidade Salgado de Oliveira. Programa de Pós-Graduação em Psicologia. Rua Marechal Deodoro, 263, Centro. Niterói-RJ, Brazil. CEP 24.030-060. E-mail: freitas.cpp@gmail.com
1990). In a professional setting, flow may be recognized as a positive and temporary experience, where one is motivate and immersed in the development of his/her work activities, and simultaneously evaluate their tasks as pleasurable (Demerouti, Bakker, Sonnentag, \& Fullagar, 2012).

The dimensions absorption, work enjoyment and intrinsic work motivation constitute flow at work (Bakker, 2008). The dimension absorption is identified as the state of immersion and absolute concentration of professionals in their work activities. Work enjoyment refers to the positive 
evaluations that professionals make about their work conditions. Intrinsic work motivation may be identified as the situations that professionals develop their work tasks due the satisfaction and the meaningfulness that professionals experience while doing their work activities (Bakker, 2008).

Flow at work is related to the development of both the organization and the professional. Flow at work is also directly related to the levels of well-being in professionals (Bakker, 2008). High levels of flow at work may result from the context of an abundance of work resources (for example, social support, self-efficacy and autonomy) (Demerouti et al., 2012; Salanova, Rodríguez-Sánchez, Schaufeli, \& Cifre, 2014). Higher levels of flow may boost the creation of new sources of work resources or the strengthening of existing ones in the workplace (for example, positive affect, optimism, and feedback from supervisors) and be associated with the impact of resources on the experience of flow at work (Salanova, Bakker, \& Llorens 2006). The presence of high levels of flow at work may also constitute as a protective factor to labor overload, buffering the negative impact of a high level of demand (Demerouti et al., 2012). In addition, the experience of high levels of flow at work of just one professional may be contagious so that work colleagues also experience flow at work (Bakker, 2005; Salanova et al., 2014).

The relation of the feedback loop of experiences of flow at work with levels of resources, and the protective role of flow experiences on the process of coping with high levels of demand, are in line with the theoretical model "broaden and build". This model proposes that the experience of positive affect on day-to-day activities contributes to strengthening of personal resources in individuals (Fredrickson, 2013). For example, the levels of occupational self-efficacy may promote increase of levels of dimensions absorption, work enjoyment, and intrinsic work motivation, and, consequently the levels of flow dimensions would boost the levels of occupational self-efficacy.

The Work-related Flow Inventory - WOLF (Bakker, 2008) has been established as a reliable tool for assessing the levels of flow at work. The original version of WOLF was developed based on a sample of Dutch professionals. This inventory is composed by 13 items that evaluate the three flow dimensions (absorption, work enjoyment and intrinsic work motivation).

In the original study (Bakker, 2008), the WOLF showed satisfactory indexes of internal consistency on the three dimensions evaluated (absorption, $\alpha$ reliability ranging from 0.75 to 0.86 , work enjoyment, $\alpha$ reliability ranging from 0.88 to 0.96 , and intrinsic work motivation, $\alpha$ reliability ranging from 0.63 to 0.88 ). The goodness-of-fit indexes of WOLF were adequate for the first-order three-factor solution $\left(\chi^{2}(372)=917.97, p<.001, \mathrm{CFI}=0.91, \mathrm{NNFI}=0.91\right.$, RMSEA $=0.04)$. Furthermore, the first-order three-factor solution was also observed on the WOLF Spanish and Italian versions (Colombo, Zito, \& Cortese, 2013; Demerouti, 2006).

It is also possible to investigate the flow scores as a general score of flow (Bakker, 2005; Salanova et al., 2006). The general score of flow at work may be evaluated through a second-order structure solution, with items loading on their expected theoretical dimensions, and the three factors loaded onto a higher-order factor of flow (Bakker, 2005; Salanova et al., 2006).

The present study aims to investigate the psychometric proprieties of the WOLF Brazilian Version. In agreement with the theoretical assumptions about flow at work (Bakker, 2008) and the factor structure of WOLF (Bakker, 2008; Colombo et al., 2013; Demerouti, 2006), it was evaluated if the first-order three-factor structure was the best solution for the Brazilian version of the WOLF.

\section{Method}

\section{Adaptation Process of the Scale}

The first step of the adaptation process of the Brazilian version of the WOLF was the translation of the questionnaire from English to Portuguese by two independent researchers (Borsa, Damásio, \& Bandeira, 2012). The two translated versions were synthesized into a preliminary adapted version. This adapted version was evaluated by a target population $(n=9)$ and by a group of researchers, psychologists and experts in the fields of psychometrics and positive psychology.

This adapted version was then back-translated from Portuguese to English by two other independent translators, and again, the study authors conducted a synthesis of the backtranslations. A group of experts evaluated the synthesized back-translated version. They verified that the translated and back-translated versions were culturally adapted, as well as semantically and idiomatically equivalent to the original version of the scale. Thus, the instrument was considered ready for use.

\section{Participants}

A total of 640 professional ( $74 \%$ women), aged 19 to 73 years $(M=35.9, S D=10.5)$ participated in this study. Among the participants, 23\% were single, $40 \%$ married, $6 \%$ divorced, $29 \%$ in a stable relationship (dating, engaged, or living with a partner), and $1 \%$ widowed. Concerning the educational level of the participants, $2 \%$ had completed high school, $14 \%$ had an undergraduate degree, and $17 \%$ had a graduate degree, $17 \%$ were doing a Post-graduation degree and $51 \%$ had a Post-graduation degree. The working time of the participants ranged from 1 year to 50 years $(M=14.4$, $S D=10.7)$. Different occupational groups were investigated in order to increase the variability of the characteristics of work contexts in which professionals could experience flow at work. This strategy avoids the results of the study be biased due to labor characteristics of a professional group, which may or may not be more likely to experience flow at work (for example, teachers) compared to other occupational groups (Demerouti, 2006). Among the participants, 14\% were health professionals, $22 \%$ education professionals, $38 \%$ were from the humanities and $26 \%$ were worked on development of products and construction. 


\section{Instruments}

Sociodemographic Questionnaire: This instrument was developed to assess the sociodemographic characteristics of the sample (for example, gender, age, marital status, educational level, financial income, presence or absence of chronic illness and/or special needs).

Work Related Flow Inventory - WOLF (Bakker, 2008): This inventory assesses the three dimensions of flow at work (absorption (4 items), work enjoyment, (4 items), and intrinsic work motivation, (5 items)). The questions are answered on a seven-point scale, ranging from 1 (never) to 7 (always). In its original version, the inventory dimensions present adequate internal consistency absorption, $\alpha=0.75$ to 0.86 , work enjoyment, $\alpha=0.88$ to 0.96 , and intrinsic work motivation, $\alpha=0.63$ to 0.88 ) and satisfactory fit indexes $\left(\chi^{2}(372)=917.97, p<0.001, \mathrm{CFI}=0.91, \mathrm{NNFI}=0.91\right.$, RMSEA = 0.04) (Bakker, 2008).

Occupational Self-Efficacy Scale - Short Form - OSSSF (Rigotti, Schyns, \& Mohr, 2008) adapted by Damásio, Freitas, and Koller (2014). This scale assesses levels of OSE. The original scale has a one-factor structure consisting of six items with satisfactory Cronbach's alpha coefficients $(\alpha=0.90)$ (Rigotti et al., 2008). In the Brazilian validation study (Damásio et al., 2014), a one-factor structure with adequate internal consistency $(\alpha=0.78)$ was observed. The items are answered on a five-point scale, ranging from 1 (completely disagree) to 5 (completely agree). In this sample, the alpha reliability coefficient and fit indexes of the instrument were satisfactory, suggesting adequacy of the scale: $\alpha=0.84$; CFI $=0.99$; TLI $=0.99$; $\operatorname{RMSEA}(90 \% \mathrm{IC})=0.11(0.07-0.14)$.

General Satisfaction at Work Scale (Silva \& Ferreira, 2009): This scale assesses satisfaction at work levels through five items Likert-type scale (ranging from 1 - Disagree strongly to 6 - Agree strongly). The scale has a one-factor structure, showing an excellent alpha reliability coefficient $(\alpha=0.80)$ (Silva \& Ferreira, 2009). The scale exhibited appropriate internal consistency and goodness-of-fit indexes in the research sample $(\alpha=0.92$; CFI $=0.99$; TLI $=0.99$; $\operatorname{RMSEA}(90 \% \mathrm{IC})=0.13(0.09-0.16))$.

\section{Procedures}

Data collection. Participants were accessed through various sources, such as personal and social media invitations, recruitment within social and occupational institutions. The total of the participants answered the questionnaires in a web-based platform, after signing the Informed Consent Form.

Data analysis. The study evaluated the evidence of the scale dimensionality, reliability and relation with external variables. The dimensionality of the scale was evaluated through confirmatory and multigroup factor analyses. The relation of flow with other variables was investigated through convergent validity. Finally, the reliability was investigated through the composite reliability.
Three confirmatory factor analyses (WLSMV estimation method) were employed to investigate the most adequate structure of the WOLF. The first model evaluated the fit indexes of the one-dimension structure, in which the 13 items loaded onto a general flow factor. The second model assessed a correlated first-order three-factor solution for the WOLF (absorption, work enjoyment and intrinsic work motivation). The third model was a second-order structure in which all three factors loaded onto a higher-order factor of flow. The goodness-of-fit indexes of the WOLF were assessed through the following fit indexes: comparative fit index (CFI), TuckerLewis index (TLI), root mean square error of approximation (RMSEA) and standardized root mean square residual (SRMR). According to the guidelines used, CFI and TLI values should be greater than 0.90, RMSEA values should be less than 0.08 to indicate acceptable fit (with a $90 \%$ confidence interval not greater than 0.10), and SRMR with values below 0.80 were considered acceptable (Brown, 2006).

Lastly, multigroup confirmatory factor analyses (MGCFAs) with the total sample were performed to test the measurement invariance of the scale for gender (female, $n=476$; male, $n=164$ ) and employment status (autonomous, $n=134$; non-autonomous, $n=506$ ) groups. Measurement invariance was evaluated by testing of configuration, metric and scalar invariance, in a hierarchical way, so that a more restricted model was compared to a less restricted model (Damásio \& DeSousa, 2015). According to model restriction, the configuration model was compared to the metric model, and the metric model was compared to the scalar model.

The models were evaluated based on the CFI $(>0.90)$, TLI $(>0.90)$, and RMSEA $(<0.08$, with the $90 \%$ confidence interval not exceeding 0.10) fit indexes. Measurement invariance was assessed based on the CFI difference values between the models (DCFI). Measurement invariance is achieved if $\triangle \mathrm{CFI}$ is lower than $0.01(\triangle C F I<.01)$ (Damásio \& DeSousa, 2015).

The reliability of the scale was assessed by internal consistency indexes of the factors through the composite reliability (Fornell \& Larcker, 1981) of the scale.

Convergent validity was assessed by the relationships of absorption, work enjoyment and intrinsic work motivation with occupational self-efficacy and satisfaction at work. The correlations were investigated through a structural equation model to control the measurement error of the model. Several hypotheses were tested simultaneously in the correlations analyses. In order to avoid familiar errors the Bonferroni correction was applied. We expected positive and low-to-moderate correlations among flow dimensions with occupational self-efficacy and satisfaction at work.

\section{Results}

\section{Confirmatory Factor Analysis}

The present study aimed to investigate the adequacy of the structure of first-order three-factor structure for the WOLF. 
In order to confirm if the first-order three-factor structure was the best solution, three models for the WOLF were tested in this sample $(n=640)$ : Model 1 assessed a one-dimension structure, with all 13 items loading onto a general flow factor; model 2 evaluated the theoretically based first-order threefactor correlated structure, in which the items loaded onto absorption, work enjoyment and intrinsic work motivation; and model 3 assessed a second-order structure, with items loading on their expected theoretical dimensions, and the three factors loaded onto a higher-order factor of flow.

The results of the first CFA showed satisfactory fit indexes for the WOLF unifatorial solution, with exception of RMSEA ( $>$ 0.08) (Table 2), the 13 items presented satisfactory loading (Table 1). The second model, which assessed a first-order three-factor structure for the WOLF, with all 13 items loading on their expected theoretical dimension, allowing the factors to correlate (see Table 1), presented acceptable fit indexes, with exception of RMSEA $(>0.08)$ (Table 2). In this model the flow dimensions were correlated (absorption with work enjoyment, $r=0.81$, absorption with intrinsic work motivation, $r=0.79$, work enjoyment with intrinsic work motivation, $r=0.87$ ). The third model (higher-order four-factor solution, in this model the factors were not allowed to correlate), also presented acceptable fit indexes, with exception of RMSEA $(>0.08)$ (Table 2). It was observed that all items showed satisfactory load on their expected theoretical dimension (Table 1). Furthermore, the factors (absorption, $b=0.91$, work enjoyment, $b=0.93$, e intrinsic work motivation, $b=0.90$ ) contributed on the constitution of the general score of flow (Table 1). As can be seen in Table 2, the index fit of models 2 and 3 are virtually identical, suggesting the acceptance of both scale versions (oblique three factors, or a general second-order factor).

Table 1

Confirmatory Factor Analysis of the Unidimensional Structure, First-Order Three-Factors and Higher-Order Three-Factor Structure of WOLF

\begin{tabular}{|c|c|c|c|c|c|c|c|}
\hline \multirow[t]{2}{*}{ Items } & \multirow{2}{*}{$\begin{array}{c}\text { Model } 1 \\
\text { Item Loading } \\
\text { Flow }\end{array}$} & \multicolumn{3}{|c|}{$\frac{\text { Model } 2}{\text { Item Loading }}$} & \multicolumn{3}{|c|}{$\frac{\text { Model } 3}{\text { Item Loading }}$} \\
\hline & & A & W.E. & IWM & A & WE & IWM \\
\hline $\begin{array}{l}\text { 1. When I am working, I think about nothing else (Quando estou } \\
\text { trabalhando, não penso em mais nada) }\end{array}$ & $0.84 *$ & $0.88 *$ & & & $0.86^{*}$ & & \\
\hline $\begin{array}{l}\text { 2. I get carried away by my work (Eu me deixo levar pelo meu } \\
\text { trabalho) }\end{array}$ & $0.88 *$ & $0.94 *$ & & & $0.93^{*}$ & & \\
\hline $\begin{array}{l}\text { 3. When I am working, I forget everything else around me (Quando } \\
\text { estou trabalhando, eu esqueço de tudo ao meu redor) }\end{array}$ & $0.84 *$ & $0.88 *$ & & & $0.87^{*}$ & & \\
\hline $\begin{array}{l}\text { 4. I am totally immersed in my work (Eu estou totalmente } \\
\text { envolvido no meu trabalho) }\end{array}$ & $0.82 *$ & $0.90 *$ & & & $0.88^{*}$ & & \\
\hline $\begin{array}{l}\text { 5. My work gives me a good feeling (Meu trabalho faz eu me } \\
\text { sentir bem) }\end{array}$ & $0.94^{*}$ & & $0.96^{*}$ & & & $0.96^{*}$ & \\
\hline $\begin{array}{l}\text { 6. I do my work with a lot of enjoyment (Eu faço meu trabalho } \\
\text { com muito prazer) }\end{array}$ & $0.93 *$ & & $0.95^{*}$ & & & $0.95^{*}$ & \\
\hline $\begin{array}{l}\text { 7. I feel happy during my work (Eu me sinto feliz durante o meu } \\
\text { trabalho) }\end{array}$ & $0.96^{*}$ & & $0.97 *$ & & & $0.97^{*}$ & \\
\hline $\begin{array}{l}\text { 8. I feel joyful when I am working (Eu me sinto alegre quando } \\
\text { estou trabalhando) }\end{array}$ & $0.96^{*}$ & & $0.97 *$ & & & $0.97 *$ & \\
\hline $\begin{array}{l}\text { 9. I would still do this work, even if I received a lower salary ( } E u \\
\text { continuaria nesse trabalho mesmo que eu recebesse um salário } \\
\text { menor) }\end{array}$ & $0.73^{*}$ & & & $0.79 *$ & & & $0.82 *$ \\
\hline $\begin{array}{l}\text { 10. I find that I also want to work in my free time (Eu percebo que } \\
\text { também quero trabalhar no meu tempo livre) }\end{array}$ & $0.67 *$ & & & $0.72 *$ & & & $0.72 *$ \\
\hline 11. I work because I enjoy it (Eu trabalho porque eu gosto) & $0.83 *$ & & & $0.90 *$ & & & $0.91 *$ \\
\hline $\begin{array}{l}\text { 12. When I am working on something, I am doing it for myself } \\
\text { (Quando estou trabalhando em alguma coisa, estou fazendo isso } \\
\text { por mim mesmo }(a) \text { ) }\end{array}$ & $0.75^{*}$ & & & $0.81 *$ & & & $0.82 *$ \\
\hline $\begin{array}{l}\text { 13. I get my motivation from the work itself, and not from the } \\
\text { reward for it (Eu me sinto motivado(a) pelo trabalho por si só, e } \\
\text { não do que recebo por ele) }\end{array}$ & $0.80^{*}$ & & & $0.86^{*}$ & & & $0.87 *$ \\
\hline Flow & & & & & $0.91 *$ & $0.93^{*}$ & $0.90 *$ \\
\hline
\end{tabular}

Note. ${ }^{*} p<0.05, \mathrm{~A}=$ Absorption, W.E. = Work Enjoyment, I.W.M. = Intrinsic Work Motivation; Model $1=$ Model One-dimension, Model 2 = Model First-Order Three-Factor Structure, Model 3 = Higher-Order Three-Factor Structure. 
Table 2

Goodness-of-Fit Indexes of the Confirmatory Factor Analyses of the Brazilian Version of WOLF

\begin{tabular}{|c|c|c|c|c|}
\hline Model & $\chi^{2}(\mathrm{gl})$ & CFI & TLI & RMSEA $(90 \% \mathrm{CI})$ \\
\hline Model 1 & $2159.27 *(65)$ & 0.96 & 0.96 & $0.22(0.22-0.23)$ \\
\hline Model 2 & $703.8 *(62)$ & 0.99 & 0.99 & $0.13(0.12-0.14)$ \\
\hline Model 3 & $720.40 *(64)$ & 0.99 & 0.99 & $0.13(0.12-0.13)$ \\
\hline
\end{tabular}

\section{Multigroup Confirmatory Factor Analysis}

Given that the multidimensional scale, with first-order three-factor structure of the Brazilian version of WOLF, presents more detailed evaluation of the flow, because it presents specific scores for each of the factors, we chose to follow the analysis using this version. Thus, the invariance of the measure, as assessed by multigroup confirmatory factor analysis (MGCFA) and evidence of validity based on external measurements were tested considering the multifactorial measure.

Goodness-of-fit indexes of the configuration model showed that the first-order three-factor structure of the Brazilian version of WOLF was acceptable in the various groups (gender, female and male; employment status, autonomous and non-autonomous). In considering the DCFI criteria (Damásio \& DeSousa, 2015), metric and scalar invariance were achieved across all subgroups (male and female, autonomous and non-autonomous; Table 3).

Reliability. Reliability coefficients of the three WOLF dimensions were assessed through composite reliability. The dimension absorption showed the value of composite reliability of 0.93 , the dimension work enjoyment of 0.98 , and intrinsic work motivation of 0.87 .

Table 3

Goodness-of-fit indexes of Brazilian version of WOLF of MGCFA to Gender and Employment Status $(n=477)$

\begin{tabular}{|c|c|c|c|c|}
\hline Gender Measurement Invariance & RMSEA $(90 \% \mathrm{CI})$ & TLI & CFI & $\Delta \mathrm{CFI}$ \\
\hline Male $(n=164)$ & $0.13(0.12-0.14)$ & 0.987 & 0.989 & - \\
\hline Female $(n=476)$ & $0.12(0.11-0.13)$ & 0.990 & 0.992 & - \\
\hline Unconstrained model & $0.12(0.11-0.13)$ & 0.989 & 0.992 & - \\
\hline Metric invariance & $0.12(0.11-0.12)$ & 0.990 & 0.992 & 0.000 \\
\hline Scalar invariance & $0.08(0.08-0.09)$ & 0.995 & 0.994 & 0.002 \\
\hline Employment Status Measurement Invariance & RMSEA $(90 \% \mathrm{CI})$ & TLI & CFI & $\Delta \mathrm{CFI}$ \\
\hline Autonomous $(n=134)$ & $0.12(0.10-0.14)$ & 0.989 & 0.991 & - \\
\hline Non-autonomous $(n=506)$ & $0.13(0.12-0.14)$ & 0.988 & 0.990 & - \\
\hline Unconstrained model & $0.12(0.11-0.13)$ & 0.989 & 0.991 & - \\
\hline Metric invariance & $0.08(0.07-0.09)$ & 0.995 & 0.994 & 0.003 \\
\hline Scalar invariance & $0.09(0.08-0.10)$ & 0.994 & 0.993 & 0.001 \\
\hline
\end{tabular}

Note: $* p<0.05$.

\section{Convergent Validity}

The results of convergent validity were investigated using the total sample $(n=640)$. Correlations of absorption, work enjoyment and intrinsic work motivation were significant and in the expected direction with the employed variables (positively associated with occupational self-efficacy and job satisfaction, Figure 1). 


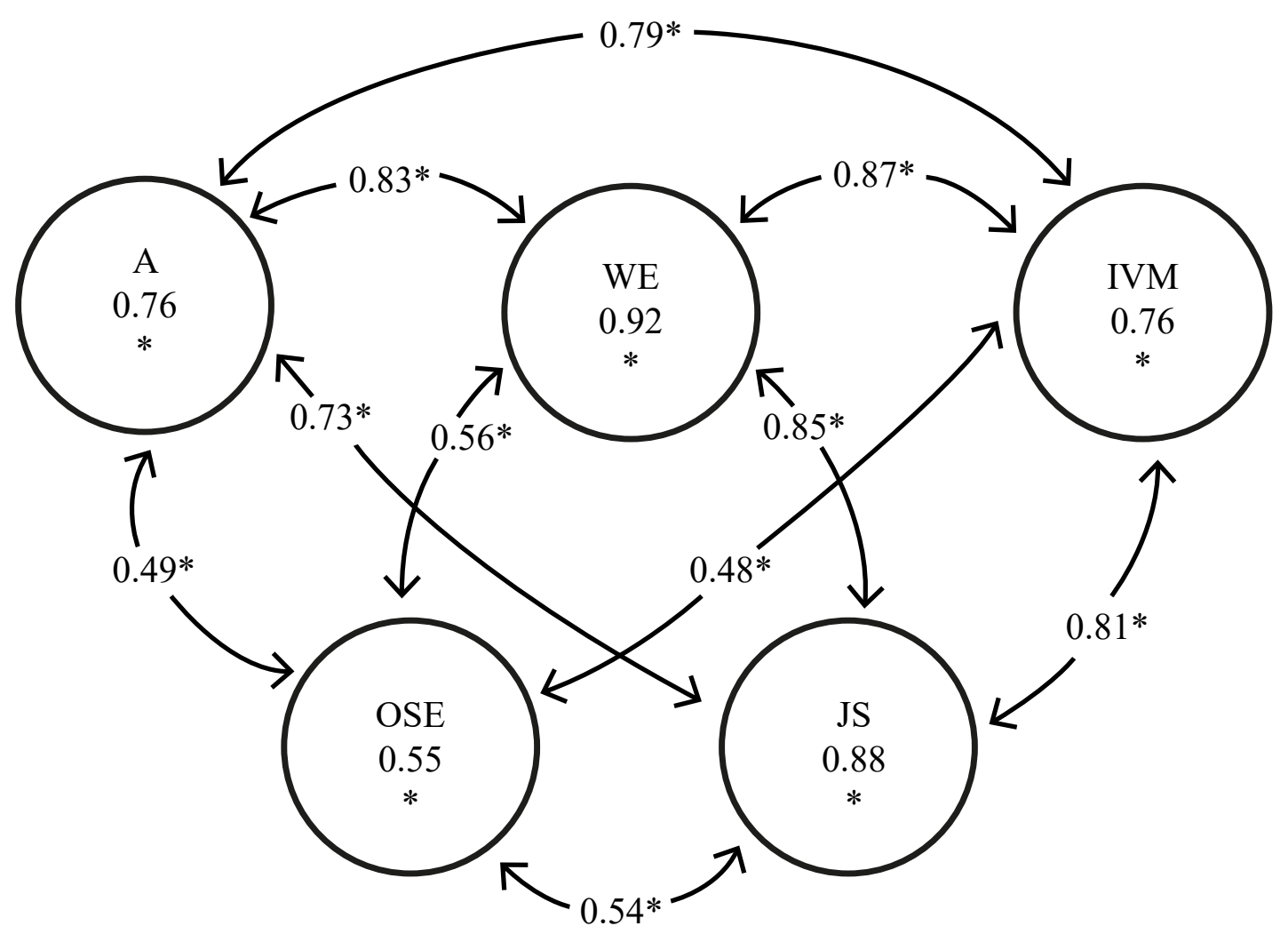

Figure 1. Variance, Standard Deviation and Correlations between WOLF and convergent measures $(n=640)$.

Note. ${ }^{*} p<.001$; OSE = Occupational Self-Efficacy; JS = Job Satisfaction; A = Absorption; WE = Work Enjoyment; and IWM = Intrinsic Work Motivation. The factor loadings of the items are not displayed to maintain parsimony of the model

\section{Discussion}

The first-order three-factor structure proved to be the most reliable solution for the Brazilian version of WOLF. The study results showed that the three dimensions of flow at work (absorption, work enjoyment, and intrinsic work motivation) may be recognized at the Brazilian working context and are aligned with the theoretical assumptions about flow at work (Bakker, 2008). Furthermore, the firstorder three-factor structure was also observed on the Spanish (Demerouti, 2006) and Italian (Colombo et al., 2013) versions of WOLF.

The flow dimensions presented strong associations among them. The relation between the dimension absorption with work enjoyment and intrinsic work motivation shows that being focused on the development of work tasks has a crucial role on the occurrence of flow at work. The association between work enjoyment and intrinsic work motivation showed that professionals with higher levels of intrinsic work motivation usually are more engaged on their occupational activities. Similarly, a greater involvement on work can lead professionals to experience higher levels of intrinsic work motivation (Bakker, 2008; Zubair \& Kamal, 2015).

The presence of high levels of flow at work may be recognized when the professionals experience high levels on the three flow dimensions. Thus, the higher the levels on the dimensions absorption, work enjoyment and intrinsic work motivation, the higher the levels of flow at work (Bakker, 2008).

It was observed that the general score of flow at work may be evaluated through a higher-order three-factor structure, in this model the three primary factors constitute a higher-order (Bakker, 2005; Salanova et al., 2006). In the present study the higher-order three-factor solution presented acceptable fit index. We highlight, however, that the use of the general score of flow at work is linked to a reduction of the information obtained through the scale, in view of the impossibility to investigate the absorption levels of engagement and intrinsic motivation separately.

The results of the MGCFAs evidenced that WOLF showed configuration, metric and scalar invariance for gender (male and female) and for employment status (autonomous and non-autonomous). These findings suggest that the WOLF can be employed in Brazilian males and females of different employment status (autonomous and non-autonomous) (Damásio \& DeSousa, 2015). The internal consistency of the WOLF dimensions indicated that the scale might be considered a reliable instrument to evaluate flow at work.

The levels of occupational self-efficacy were positively related to the dimensions of flow at work (absorption, work enjoyment, and intrinsic work motivation). The occupational self-efficacy may be defined as the professionals' perceptions 
of their abilities to perform their work tasks effectively (Rigotti et al., 2008). Due to levels of occupational selfefficacy influence the investments that professionals will perform, the occupational self-efficacy may impact over the levels of motivation and involvement of individuals in the development of work tasks (Del Líbano, Llorens, Salanova, \& Schaufeli, 2012). The relation of occupational self-efficacy and dimensions of flow at work explicit that the state of wellbeing results from a cyclic process, wherein the resources at work (for example, occupational self-efficacy) promote the well-being (for example, flow work), and the reverse is true (Salanova et al., 2014; Zubair \& Kamal, 2015). For example, professionals that often experience flow at work may feel motivated to develop their work, and consequently present higher levels of occupational self-efficacy (Salanova et al., 2014; Zubair \& Kamal, 2015). These results corroborate that experience flow at work contribute to the strengthening of personal resources of professionals, as proposed on the theoretical model of "broaden and build" (Demerouti et al., 2012; Fredrickson, 2013).

The presence of higher levels of job satisfaction was associated with higher levels of absorption, work enjoyment and intrinsic work motivation. Job satisfaction refers to the professionals' evaluations about their work conditions (Del Líbano et al., 2012). In such a way, professionals who evaluate their work conditions positively may experience flow at work more often (Bakker, 2008).

One of the strength of the present study was the robustness of the data analysis procedures used. Exploratory and confirmatory factor analyses were performed with corrections for data non-normality, considering the instrument scores as ordinal and non-scalar variables (L.K. Muthén \& B.O. Muthén, 2010). One other strength of this study was the diversity of the sample. The inclusion of professionals of different occupational groups enabled the extension of the variance of the constructs investigated. Because of the heterogeneity of the sample, the results may be generalized to different occupational contexts.

The limitations of this study are the use of a nonrepresentative sample, the absence of an occupational group that experience extremely high levels of flow (for example, dancers) and the exclusive use of self-report instruments. Further studies should investigate the evidence of validity of WOLF in other occupational groups, in a way to advance the findings of the present research. For example, others studies should evaluate the WOLF psychometric properties on occupational groups that usually show extremely high levels of flow, like musicians, as well as individuals that are exclusively dedicated to religious institutions, like priests, and volunteer workers.

The major contribution of this study was to present evidence on the validity of the Brazilian version of the WOLF. Our results demonstrated the adequacy of the construct validity of the measure, suggesting its possible use in future studies. WOLF may constitute a useful tool to assess absorption, work enjoyment and intrinsic work motivation, as well as the general score of flow. The use of WOLF may be advantageous because it allows that professionals well-being, involvement at work and motivation be evaluated through a brief scale. The possibility of evaluate professionals wellbeing levels on a day-to-day bases allows that the process of resources development be mapped on the work context. This information may be useful as evidence to plan interventions to promote workers' health, well-being and safety.

\section{References}

Bakker, A. B. (2005). Flow among music teachers and their students: The crossover of peak experiences. Journal of Vocational Behavior, 66(1), 26-44. doi:10.1016/j.jvb.2003.11.001

Bakker, A. B. (2008). The work-related flow inventory: Construction and initial validation of the WOLF. Journal of Vocational Behavior, 72(3), 400-414. doi:10.1016/j.jvb.2007.11.007

Borsa, J. C., Damásio, B. F., \& Bandeira, D. R. (2012). Adaptação e validação de instrumentos psicológicos entre culturas: Algumas considerações [Cross-cultural adaptation and validation of psychological instruments: Some considerations]. Paidéia (Ribeirão Preto), 22(53), 423-432. doi:10.1590/S0103-863X2012000300014

Brown, T. A. (2006). Confirmatory factor analysis for applied research. New York, NY: Guilford.

Colombo, L., Zito, M., \& Cortese, C. G. (2013). The Italian version of the WOrk-reLated Flow inventory (WOLF): First psychometric evaluations. BPA - Applied Psychology Bulletin, 61(268), 37-42.

Csikszentmihalyi, M. (1990). Flow: The psychology of optimal experience. New York, NY: Harper Collins.

Damásio, B. F., \& DeSousa, D. A. (2015). Análise fatorial confirmatória multigrupo: Descrição e aplicação no software Mplus [Multigroup confirmatory factor analysis: Description and application in Mplus software]. In M. C. R. Silva, D. Bartholomeu, C. M. M. Vendramini, \& J. M. Montiel (Orgs.), Aplicações de métodos estatísticos avançados à avaliação psicológica e educacional [Applications of statistical methods to advanced psychological assessment and educational] (pp. 175-192). São Paulo, SP: Vetor.

Damásio, B. F., Freitas, C. P. P., \& Koller, S. H. (2014). Occupational Self-Efficacy Scale - Short Form (OSSSF): Adaptation and evidence of construct validity of the Brazilian version. Revista Brasileira de Orientação Profissional, 15(1), 65-74. Retrieved from http://pepsic.bvsalud.org/pdf/rbop/v15n1/08.pdf

Del Líbano, M., Llorens, S., Salanova, M., \& Schaufeli, W. B. (2012). About the dark and bright sides of selfefficacy: Workaholism and work engagement. The Spanish Journal of Psychology, 15(2), 688-701. doi:10.5209/rev_SJOP.2012.v15.n2.38883 
Demerouti, E. (2006). Job characteristics, flow, and performance: The moderating role of conscientiousness. Journal of Occupational Health Psychology, 11(3), 266-280. doi:10.1037/1076-8998.11.3.266

Demerouti, E., Bakker, A. B., Sonnentag, S., \& Fullagar, C. J. (2012). Work-related flow and energy at work and at home: A study on the role of daily recovery. Journal of Organizational Behavior, 33(2), 276-295. doi:10.1002/job.760

Fornell, C., \& Larcker, D. F. (1981). Evaluating structural equations models with unobservable variables and measurement error. Journal of Marketing Research, 18(1), 39-50. doi: $10.2307 / 3151312$

Fredrickson, B. L. (2013). Positive emotions broaden and build. In P. Devine \& A. Plant (Eds.), Advances in experimental social psychology (Vol. 47, pp. 1-53). Amsterdam, The Netherlands: Elsevier.

Hayton, J. C., Allen, D. G., \& Scarpello, V. (2004). Factor retention decisions in exploratory factor analysis: A tutorial on parallel analysis. Organizational Research Methods, 7(2), 191-205. doi:10.1177/1094428104263675

Horn, J. L. (1965). A rationale and test for the number of factors in factor analysis. Psychometrika, 30(2), 179-185. doi:10.1007/BF02289447

Kaiser, H. F. (1960). The application of electronic computers to factor analysis. Educational and Psychological Measurement, 20(1), 141-151. doi:10.1177/001316446002000116

Muthén, L. K., \& Muthén, B. O. (2010). Mplus: Statistical analysis with latent variables: User's guide (6th ed.). Los Angeles, CA: Muthén \& Muthén.

Rigotti, T., Schyns, B., \& Mohr, G. (2008). A short version of the occupational self-efficacy scale: Structural and construct validity across five countries. Journal of Career Assessment, 16(2), 238-255. doi:10.1177/1069072707305763

Salanova, M., Bakker, A. B., \& Llorens, S. (2006). Flow at work: Evidence for an upward spiral of personal and organizational resources. Journal of Happiness Studies, 7(1), 1-22. doi:10.1007/s10902-005-8854-8

Salanova, M., Rodríguez-Sánchez, A. M., Schaufeli, W. B., \& Cifre, E. (2014). Flowing together: A longitudinal study of collective efficacy and collective flow among workgroups. The Journal of Psychology, 148(4), 435-455. doi:10.1080/00223980.2013.806290

Silva, A. P. C., \& Ferreira, M. C. (2009). Escala de Satisfação Geral no Trabalho [Scale of General Satisfaction at Work]. Anais do Congresso Brasileiro de Avaliação Psicológica, 4, 246.

Zubair, A., \& Kamal, A. (2015). Authentic leadership and creativity: Mediating role of work - related flow and psychological capital. Journal of Behavioural Sciences, 25(1), 150-171.
Clarissa Pinto Pizarro de Freitas is a Professor of the PostGraduation Program in Psychology of Universidade Salgado de Oliveira, Niterói-RJ, Brazil.

Bruno Figueiredo Damásio is a Professor of the Institute of Psychology of the Universidade Federal do Rio de Janeiro, Rio de Janeiro-RJ, Brazil.

Emily Jean Haddad is a PhD Candidate in Post-Graduate Program in Psychology of the Universidade Federal do Rio Grande do Sul, Porto Alegre-RS, Brazil.

Silvia Helena Koller is a Professor in the Post-Graduate Program in Psychology of the Universidade Federal do Rio Grande do Sul, Porto Alegre-RS, Brazil.

\section{Authors' Contribution:}

All authors made substantial contributions to the conception and design of this study, to data analysis and interpretation, and to the manuscript revision and approval of the final version. All the authors assume public responsability for content of the manuscript.

Received: Jun. 6, 2016

1st Revision: Nov. 1, 2016

Approved: Mar. 14, 2017

How to cite this article:

Freitas, C. P. P., Damásio, B. F., Haddad, E. J., \& Koller, S. H. (2019). Work-Related Flow Inventory: Evidence of Validity of the Brazilian Version. Paidéia (Ribeirão Preto), 29, e2901. doi: http://dx.doi.org/10.1590/1982-4327e2901 